\title{
Trade, Energy Consumption, Economic Growth and Ecological Quality: An Empirical Evidence from D-8 and G-7 Countries
}

Muhammad Tariq Majeed ( $\nabla$ tariq@qau.edu.pk)

Quaid-i-Azam University https://orcid.org/0000-0001-9374-5025

Naveed Asghar

Quaid-i-Azam University

\section{Research Article}

Keywords: Aggregate and disaggregate energy consumption, Ecological degradation, Trade

Posted Date: April 21st, 2021

DOI: https://doi.org/10.21203/rs.3.rs-338481/v1

License: @ (i) This work is licensed under a Creative Commons Attribution 4.0 International License. Read Full License 


\section{Abstract}

While pursuing sustainable growth there is a need to inculcate the procedure of a sustainable environment for coming generations. This study investigates the association between carbon dioxide emissions $\left(\mathrm{CO}_{2}\right)$ and gross domestic product (GDP), disaggregate and aggregate energy usage, trade, using yearly data for the time component of 1980-2019 for D-8 and G-7 countries. The study employs second-generation unit root tests namely cross sectionally augmented Dickey Fuller (CADF) and cross sectionally augmented IPS (CIPS). Further, Kao, Pedroni, and Westerlund cointegration tests are employed to test for cointegration. To estimate models, fully modified least squares (FMOLS), dynamic ordinary least squares (DOLS) and heterogeneous panel estimators (MG, AMG, CCEMG, DCCEMG) are used. Finally, to verify the causality among the study variables the Dumitrescu and Hurlin, (2012) causality test is used. The findings of the study reveal that income, aggregate, and disaggregate energy consumptions (oil, coal, gas), and trade exacerbate ecological quality in D-8 countries while income and trade improve it in G-7 economies. However, oil, coal, and gas usage are detrimental for ecological quality in G-7 economies. The study validates an inverted U-shaped environmental Kuznets curve in D-8 while U-shaped in G-7 countries. It is recommended that both groups of countries need to adopt green strategies and sustainable patterns for growth and development.

\section{Introduction}

Ecological degradation is a very primitive topic that has been under discussion since the 20th century. An increasing rate of global carbon emissions is considered the major determinant of deteriorating ecological quality. The agglomeration of $\mathrm{CO}_{2}$ emissions in the atmosphere has intensified by almost 45 percent in the previous 130 years (Carbon footprint, 2018). British Petroleum (2018) highlighted that level of $\mathrm{CO}_{2}$ emissions intensified from 29,714.2 million tons in 2009 to $33,444.0$ million tons in 2017. Global climate change persistently threatening the lives and assets, thus restraining the climate changes is a concern of urgency.

Resultantly, climate change has become a momentous global concern. The implication of mitigating $\mathrm{CO}_{2}$ for opposing the worldwide ecological changes vulnerabilities, via refining ecological conditions, has been properly recognized in the international perspective. As per the execution of the Kyoto protocol in 1997, under the United Nations Convention on climate change, has stressed curbing $\mathrm{CO}_{2}$ emissions globally. IPCC (2018) projected that to maintain the worldwide temperature at 1.5 _C above the pre-industrial stages, the worldwide emissions have to be fetched down by about $45 \%$ from the level where it was in 2010 till 2030 and secondly, totally bump off it by 2050 . According to a recent global climate risk index report, countries largely affected by climate change are mainly developing economies (Eckstein et al., 2019).

Energy is a fundamental factor used in the manufacturing course and enhancing the industrial expansion and economic progress, but the high level of energy consumption increases $\mathrm{CO}_{2}$ emissions which further deteriorate environmental quality (Alkhatlan \& Javid, 2013). In the current era, many countries are now predominantly based on the utilization of fossil fuel which include coal, oil, and natural gas and they bring severe changes in the ecological condition worldwide. The rapidity of securing energy sources leads to 
intensifying the energy demand among the leading economies of the world (Munir \& Riaz, 2020). Similarly, a report by ElA (2016) states that energy demand will grow by 50 percent projected from 2005 to 2030.

The motivation for selecting D-8 economies comes from the fact that these economies are ranked as the top economies of total ecological footprint in global hectors (Global footprint Network, 2016). In 1980 the level of emissions in D-8 region was 10.00 metric tons per capita (MTPC) and raised up to 27.26 MTPC in 2019. The energy usage in 1980 was $4376.30 \mathrm{~kg}$ of oil equivalent per capita (KOEPC) and 10589.24 KOEPC in 2019 burgeoning with the growth rate of $141.97 \%$. The coal consumption was 9.91 million tons of oil equivalent (MTOE) in 1980 and upsurge to 121.83 MTOE in 2019. Similarly, oil usage in 1980 was 96.12 and intensified to $320.41 \mathrm{MTOE}$ in 2019 with the growth rate of 1.26 in the region. The gas usage increased from 20.49 in 1980 to 381.82 MTOE in 2019 with the growth rate of 12.42 times.

The G-7 economies represent the developed world. These economies use renewable energy resources, green technologies, with stringent rules trying to meet the path of sustainable economic progress. In G-8 region 84.42 MTPC $\mathrm{CO}_{2}$ emission was recorded in 1980 but in 2019 the trend of emissions goes down to 66.42 MTPC and average growth during the period 1980-2019 was $0.93 \%$. The energy usage in 1980 was 32602.12 and $31063.40 \mathrm{KOEPC}$ in 2019 and the growth rate was $0.99 \%$. The coal consumption was 705.72 MTOE in 1980 and slackened to 605.78 MTOE in 2019. However, the average growth rate was $0.97 \%$. Similarly, oil usage in 1980 was 1597.60 and reduce to 1525.88 MTOE in 2019 with the growth rate of 0.99 $\%$ in the G-8 region. The gas usage increased from 660.36 in 1980 to 1075.11 MTOE in 2019 with the growth rate of $1.07 \%$.

Now the economists, eco-activists, and policymakers are increasingly paying attention to analyze the associations among growth, trade, energy, and ecological degradation. To explore the association between economic development and ecological degradation famous Environmental Kuznets Curve (EKC) hypothesis states that the ecological quality starts to degrade at the preliminary level of economic development, and the quality of the environment improves as the economy grows (Grossman \& Krueger, 1991).

Theoretically the effect of trade on ecological quality is not certain. As opponents argued that growth and liberalization of trade cause systematic harm to the earth's natural resources. Similarly, increasing trade flows elevate fuel consumption as it is extensively used in the energy generation and transportation. The study of Grossman \& Krueger, (1995) highlighted that how foreign trade affects the ecological quality, depends on the various effects of trade on the economy it can be through scale effect, technological effect, and lastly technological effect. Scale effect claims that trade escalates the scale of yield and economic growth level, but the aftermath will be that this will intensify the level of $\mathrm{CO}_{2} \mathrm{emissions}$ due to more production and usage of energy. Secondly, the composition effect whereas free trade moves the country's production where it has a comparative advantage. The last technological effect says that trade can bring competitiveness, efficacy, and environment-friendly, clean technologies that will mitigate the emissions. However, it depends on the magnitude of these effects, what will be the effect of trade volume on $\mathrm{CO}_{2}$ emissions positive or negative. 
This study contributes to existing literature on ecological degradation in several ways. Firstly, this study segregates non-renewable energy sources (oil, coal, gas) consumption to explore the how these sources affect ecological quality in both regions. Moreover, the current study analyzes the impact of aggregate energy use on ecological quality as well. Secondly, the current study uses a panel data set of D-8 countries, and G-7 economies and conducted a comprehensive comparative analysis that how macroeconomic indicators (growth, trade) are contributing to ecological quality. Thirdly, the validity of EKC hypothesis is tested for both groups as well as country level. Fourthly, to deal with different econometric issues this study employs second-generation panel techniques and heterogenous panel estimators which include MG, AMG, CCEMG, DCCEMG to provide better, robust, and conclusive findings.

The research is presented as follows: Sect. 2 takes an evocative review of existing literature and section three elaborates the methodology, theoretical framework, and empirical model and section four data and variables and section five results and discussions, section six will conclude the study.

\section{Literature Review}

The theoretical framework for this study is based on the environmental Kuznets curve (EKC) theory which suggest that initially economic growth degrades the environment but after a certain level of growth, environmental degradation starts declining. The EKC has been substantially studied but the empirical validity of EKC is mixed. Since the pioneering work by Grossman \& Krueger (1991), Holtz-Eakin \& Selden (1995), Narayan \& Narayan (2010), Ahmed et al. (2016) supported inverted U-shaped relationships. Studies have typically adopted different types of data sets in analyzing the EKC hypothesis (e.g. Panayotou, 1993; Apergis et al., 2010; Kahia et al., 2019). These studies provide mixed outcomes. Apergis et al. (2010) did not confirm the hypothesis as there was a positive and linear effect of growth on emissions.

\subsection{Energy Consumption and Ecological Quality}

In this recent age of advancement, energy is considered an indispensable factor for economic expansion but also a vital strategic reserve for an economy. Similarly, sustainable economic progress relies on energy consumption (Kraft \& Kraft, 1978). The study of Ozokeu and Ozedmir (2017) indicated that a surge in energy use will be pernicious for ecological quality in both developed and emerging states. Empirical evidence of Majeed \& Mazhar (2019b) demonstrated the impact of energy consumption on $\mathrm{CO}_{2}$ emissions by using data of 131 economies (1971-2017). The results suggested that energy consumption is deleterious for the environment. Similar findings have been highlighted by Kohler, (2013) in South Africa, and Baek, (2015) in Arctic economies. The study by Dogan et al. (2017) examined the nexus between energy usage and ecological degradation using data (1981-2016) of OECD economies. The results confirmed that energy consumption is a significant indicator in deteriorating ecological quality. Furthermore, the study of kasman \& Duman (2015) on EU members economies, concluded that energy usage is detrimental for environment. The study of Gours \& Aydin (2019) examined the causal relationships among the carbon dioxide emissions, and energy consumption. However, energy consumption cause escalation in $\mathrm{CO}_{2}$ emissions in the case of MENA countries. 


\subsection{Coal, Oil, Gas and Ecological Quality}

The consumption of coal, oil, and gas has escorted severe changes in the ecological condition worldwide. A report published by the European Union Joint Research Centre, elaborated that the combustion of fossil fuel accounted for about 90 percent of total worldwide $\mathrm{CO}_{2}$ emissions (Oliver et al., 2012). Every non-renewable source either gas, coal, or oil has a calamitous effect on the environment at both levels, whether it is extraction or consumption of the resource. A report by British petroleum (2020) highlighted that at the global level energy usage upsurges the level of emissions by 2.3 percent. Moreover, elevation in oil consumption by 0.9 percent, gas consumption and production 2 and 3.4 percent was observed especially in emerging countries. But globally there was a reduction in coal consumption by 0.6 percent other than the case of OECD economies where a reduction in its demand was observed. The recent literature suggests that disaggregated research at regional or national levels is more felicitous (Li et al., 2018).

Empirical evidence supports that raising the level of oil, coal, and consumption are exacerbating ecological quality. According to a study by Alkhathlan \& Javid (2013) using autoregressive distributive lag (ARDL) over the period from 1980-2011 analyzed that oil, coal, and gas usage are positively associated with $\mathrm{CO}_{2}$ emissions. The study by Khan et al. (2019) concludes that coal, oil, and natural gas consumption escalate environmental degradation. Likewise, using the data of South Asian economies Munir and Riaz (2019) concluded that coal, oil, and gas usage are increasing the level of $\mathrm{CO}_{2}$ emissions in the region. Similarly, another study by Valadkhani et al. (2019) examined the threshold effects of oil, coal, and gas on $\mathrm{CO}_{2}$ emissions for the panel data set of 79 countries from 1965 to 2017. The results of the study confirmed that an increase in the consumption of oil, coal, and gas intensifies the level of $\mathrm{CO}_{2}$ emissions. A recent study by Munir \& Riaz (2020) investigated the impact of oil, coal, gas, and electricity consumption by applying the econometric technique non-linear autoregressive distributive lag (NARDL) for the time from 1975 to 2018 in the case of the United States of America, China and Australia on ecological degradation. The results indicate that oil, coal, and gas are significant factors in enhancing the $\mathrm{CO}_{2}$ emissions in the USA, in Australia, oil and coal are the main contributors to escalating emissions, and lastly in china oil, and gas are key factors that increasing the level of $\mathrm{CO}_{2}$ emissions. Shabaz et al. (2013) documented that coal consumption is a major factor in raising emissions in South Africa.

\subsection{Trade and Ecological Quality}

The famous theory of trade Hecksher-Ohlin trade recommends that if there is free trade developing economies should specialize in manufacturing and exporting those goods which are plentiful or cheap for instance labor and ample natural resources while on other hand developed nations will lead towards capital intensive affairs. Trade necessitates the transfer of goods from a country to another country. Sometimes it can be for consumption or it can be for further processing. This indicates that pollution is usually generated during production and consumption is in other countries. Now, more engagement of developing economies into foreign trade has made trade openness imperative discussion for the EKC hypothesis (Stern et al., 1994; Lean \& Smyth, 2010; Baek, 2015). 
Shafik and Bandyopadhyay (1992) recommend that an economy that is more open to trade will be less polluted. The reason is when the economies are more open, they face an advanced level of competition and they must invest in advance efficient technologies which in return leads towards lessening pollution. Suri and Chapman (1998) discussed the trade in both form energy-intensive and second is non-energy intensive commodities. For instance, in the case of non-energy intensive production of automobiles needs more pollution-intensive inputs. The industrialized economies usually manage by exporting those more energyintensive goods to curtail the level of pollution. On the other hand, developing economies face the challenge of mounting pollution due to more exports of energy-intensive products. This hypothesis got more interest in the previous literature, which is known as the famous displacement or PHH hypothesis (Kellenberg, 2009; Kearsley \& Riddel, 2010).

Trade can ameliorate and degrade ecological quality. To boost growth, production is elevated which needs more energy to bring resurgence in output and repercussion will be high emissions; it is known as scale effect. Similarly, if the process of production is more energy intensive and comprised by primary commodities, it causes more emissions and is said composition effect. Although, advanced technologies or substitution with green technology improve ecological quality and this is called technological effect (Grossman \& Krueger 1995; Antweiler et al., 2001). The study of Zafar et al. 2019 concluded that trade can curb ecological degradation if the technological effect is higher than both scale and composition effect.

Secondly, a surge in exports of natural resources like coal, gas especially its extraction through conventional means, deforestation dissipates natural resources, and the repercussion will be an escalation in $\mathrm{CO}_{2}$ emissions a worse ecological quality (Schmalensee et al., 1998).

The empirical evidence shows mixed results, like trade may worse, improve, or may have an insignificant effect on ecological quality. In the case of developing economies, a recent study by Van Tran (2020) explored the repercussion of international trade on ecological quality. Two-step system Generalized method of moments (GMM) was employed for the period 1971 to 2016. Results of the study indicate that a $1 \%$ surge in trade openness leads to $0.2 \%$ proliferation in $\mathrm{CO}_{2}$ emissions in the case of 66 developing countries. Fang et al. (2019) used the panel data set of 82 developing nations for the period from 1970 to 2014 to explore the impact of the quality of exports on $\mathrm{CO}_{2}$ emissions utilizing the fixed effect estimation technique. Al-Mulali \& Ozturk, (2015) employed FMOLS and investigated the reason for environmental degradation during the period 1996 to 2012 and concluded that trade damages the ecological quality in the case of 14 MENA economies. Al-Mulali \& Sheau-Ting (2014) empirically investigated the data set of 189 countries of different regions. The study used Fully modified least square (FMOLS) for the period from 1990 to 2011. The results of the study confirmed a positive relationship between trade variables (Sum of exports of goods and services and imports) and $\mathrm{CO}_{2}$ emissions. The study of Salman et al. (2019) using panel quantile regression validate that both imports and exports have unpropitious effects to improve the ecological quality in ASEAN economies.

Similarly, the study of Ahemd et al. 2019 in the case of D-8 economies examined how exports affect the environment using panel data for the time 1980-2014. The study employed the FMOLS and the DOLS 
method and the result confirmed that exports adversely affect ecological quality moreover, similar findings were concluded by Rahman (2017) in the case of China.

Contrary to this, studies also analyzed that trade may compact on $\mathrm{CO}_{2}$ emissions. A study by Jayanthakumaran et al. (2012) explored the relationship between trade and $\mathrm{CO}_{2}$ emissions in the case of China and India. The study used the time series data of India and China for the period from 1971 to 2007. The results of ARDL concludes that international trade tends to reduce $\mathrm{CO}_{2}$ emissions in the short run. Furthermore, an empirical examination of the causal association between trade openness and environmental pollution was carried out by (Ahmed et al., 2016). The data of BRICS economies was utilized for the time 1970-2013. The result of FMOLS confirmed that trade openness mitigates $\mathrm{CO}_{2}$ emissions in the long run as deforestation amongst the main concern.

Aller et al. (2015) using the Three-stage least square (3SLS) technique, indicates that in low-income countries indirect effects of trade harm the ecological conditions while it improves the environmental conditions in high-income countries. In the existing literature, few studies have mixed findings. The study by Le et al. (2016) observed the data set of 98 countries (1990-2013) utilizing the GMM approach. The study found that trade openness is good for the environment in high-income countries, and it pollutes the environment in developing economies.

\section{Methodology}

\subsection{Theoretical Framework}

Different Studies had discussed the impact of Growth, trade, and FDI on $\mathrm{CO}_{2}$ emissions. A study by Grossman \& Kruger (1991), Examined the EKC which elaborates the relationship between economic development and ecological degradation with an inverted U-Shaped curve. Previously equation used by different studies (Holtz-Eakin \& Selden, 1995; Chandran \& Tang, 2013) is as:

$$
\text { Enviromental degradation }_{i t}=f\left(G D P, G D P^{2}\right) \text { it }
$$

\subsection{Empirical Model and variable Description}

Generally, in existing literature, carbon emission is a proxy used for ecological degradation (Ozturk \& Acarvic, 2013; Ozokeu \& Ozdemir, 2017). Therefore, to understand the relationship between environmental distortion and trade, growth, aggregate and disaggregate energy usage, our model specified as by Halicioglu \& Ketenci (2016) and formulation for the impact of trade on the environment was as:

$$
\operatorname{lnCO2} 2_{i t}=\beta_{o}+\beta_{1} \ln G D P_{i t}+\beta_{2} \ln G D P^{2}{ }_{i t}+\beta_{3} \ln E c_{i t}+\beta_{4} \ln T R_{i t}+\varepsilon_{t}
$$

In above eq. $1 \mathrm{CO}_{2 i t}$ is the $\mathrm{CO}_{2}$ emissions per capita measured in Metric tons, ENRG is the energy used per capita measured in $\mathrm{Kg}$ of oil equivalent, GDP is per capita GDP measured in US\$ Constant 2010, GDP ${ }^{2}$ is 
square of GDP following the EKC hypothesis and measure of trade EXP and IMP are measured in current US\$. Since to measure estimates log-linear transformation of eq. 1 is being made to make interpretation easier in percentage form.

Extensive energy usage of non-renewable sources is pernicious for the environment as well as leads economies towards an unstainable path of development. This study will assess the association between the segregation of non-renewable energy usage namely oil, gas, and coal consumption, specified in equation 2:

$$
\ln C O_{2 i t}=\beta_{0}+\beta_{1} \ln G D P_{i t}+\beta_{2} \ln G D P^{2}{ }_{i t}+\beta_{3} \ln T R_{i t}+\beta_{4} \ln P C C_{i t}+\beta_{5} \ln P O C_{i t}+\beta_{6} \ln P G C_{i t}+\varepsilon_{i t}
$$

The above model is used for both in the case of D-8 and G-7 countries. Here, in eq. 2 In represents the natural log for each variable. The proxies used for ecological degradation $\mathrm{CO} 2$ emissions (Kt), emissions which are originated from the consumption of fossils fuels and the production of cement, which includes the usage of gas, liquid, and solid fuels. GDP is GDP per capita constant 2010 US\$ and POC, PGC, PCC are per capita oil, gas, and coal consumption. TR is the sum of merchandise imports current US\$ and merchandise exports current US\$. All the variables collected are in per capita form except imports and exports; therefore, these two variables are divided by the respective country population to transform them into per capita form. Energy use is measured in $\mathrm{kg}$ of oil equivalent per capita.

\subsection{Data and Econometric Tools}

The data of $\mathrm{CO}_{2}$ emissions, GDP per capita, energy consumption, trade volume (imports + exports), and the total population is retrieved from WDI while data regarding disaggregate consumption which includes oil, coal, and gas consumption is taken from British petroleum 2019. D-8 economies include Bangladesh, Egypt, Indonesia, Iran, Malaysia, Nigeria, Pakistan and Turkey. G-7 economies comprise Canada, France, Italy, Japan, United Kingdom and United States.

As the study uses panel time-series data, so different tests of panel unit root which includes Levin, Lin \& Chu (LLC), I'm, Pesaran (IPS) and from second-generation unit root tests, CIPs, and CADF tests will be used to examine whether data is stationary or non-stationary (Pesaran, 2007). To test cointegration among variables, Pedroni, Kao, cointegration test, proposed by (Kao, 1999; Pedroni, 1999) and the test suggested by Westerlund (2007) and Westerlund (2008), consider four tests that include two group stats and twopanel statistics. Furthermore, it also allows cross-sectional dependence (CD).

This study used FMOLS, and DOLS to estimates the results. It provides robust findings and efficaciously analyze the small sample size. The FMOLS and DOLS also consider the serial correlation and account endogeneity in the regressors but it does not account CD. However, unlike earlier studies, the current study control for distinct economic and econometric concerns which include (cross-sectional dependence, endogeneity, and heterogeneity) using distinct empirical approaches, thereby producing consistent and robust outcomes for policy designs. Likewise, Mean Group (MG) Pesaran \& smith (1995), Augmented Mean Group (AMG) (Bond \& Eberhardt, (2009). The study also uses the common correlated effect (CCE) 
estimation technique proposed by Pesaran (2006), and the dynamic CCE (DCCE) estimator developed by (Chidik \& Pesaran, 2015). The Dumitrescu \& Hurlin (2012) causality test will be used to examine the causality among the variables.

The descriptive statistics of the variables are presented in Table 1. Every economy has a different level of emissions. The maximum value of $\mathrm{CO} 2$ emissions in D-8 countries is $661710.2 \mathrm{kt}$ in Iran in 2016 and the minimum is $7638.361 \mathrm{kt}$ in 1980 in Bangladesh. In the case of G-7 economies in 2005 the highest level of emissions recorded in the United states 5789727. and minimum value in France 303275.6 kt in 2014.

Moreover, the findings of the correlation matrix are presented in table 2 . All the study variables are correlated as expected.

Table 1 Descriptive Statistics

\begin{tabular}{|c|c|c|c|c|c|}
\hline \multicolumn{6}{|c|}{$\mathrm{D}-8$} \\
\hline Variables & Mean & Median & Maximum & Minimum & Std. Dev. \\
\hline $\mathrm{CO}_{2}$ & 185341.5 & 149371.6 & 661710.2 & 7638.361 & 150563.1 \\
\hline GDP & 3880.868 & 2641.154 & 15190.10 & 359.4563 & 3423.746 \\
\hline TR & 98173.01 & 46885.00 & 465057.0 & 2889.000 & 116970.1 \\
\hline $\mathrm{CC}$ & 7.912965 & 1.628328 & 61.55799 & 0.029489 & 12.66427 \\
\hline $\mathrm{OC}$ & 31.56721 & 26.66520 & 99.88875 & 1.508813 & 23.58642 \\
\hline GC & 25.6 & 450 & 193. & 227 & 30.83025 \\
\hline ENG & 1009.207 & 808.1769 & 3060.387 & 104.8616 & 794.1035 \\
\hline \multicolumn{6}{|c|}{ G-7 } \\
\hline $\mathrm{CO}_{2}$ & 1268177. & 546300.5 & 5789727. & 303275.6 & 1609945. \\
\hline GDP & 37614.37 & 37316.41 & 55753.14 & 21684.69 & 7278.636 \\
\hline TR & -4.685168 & -4.610 & -3.535 & -5.993 & 0.592 \\
\hline CC & 106 & 38.934 & 545.740 & 7.600 & 149.034 \\
\hline $\mathbf{O C}$ & 224.4 & 99.799 & 972.722 & 58.512 & 264.211 \\
\hline GC & 122.8966 & 63.857 & 702.600 & 21.132 & 164.085 \\
\hline ENG & 4686.120 & 3946.357 & 8455.547 & -3523.025 & 2020.121 \\
\hline
\end{tabular}

Table 2 Correlation Matrix 


\begin{tabular}{|c|c|c|c|c|c|c|}
\hline \multicolumn{7}{|c|}{ D-8 (Model 1) } \\
\hline Correlation & $\mathrm{CO} 2$ & GDP & TR & PCC & POC & PGC \\
\hline $\mathrm{CO}_{2}$ & 1.000000 & & & & & \\
\hline GDP & 0.705751 & 1.000000 & & & & \\
\hline TR & 0.257015 & 0.586160 & 1.000000 & & & \\
\hline PCC & 0.625522 & 0.800763 & 0.571116 & 1.000000 & & \\
\hline POC & 0.695571 & \begin{tabular}{|l|}
0.876339 \\
\end{tabular} & 0.480805 & 0.624072 & 1.000000 & \\
\hline PGC & 0.572578 & \begin{tabular}{|l|}
0.514499 \\
\end{tabular} & 0.535804 & 0.268481 & 0.592322 & 1.000000 \\
\hline \multicolumn{7}{|c|}{ G-7(Model 2) } \\
\hline $\mathrm{CO}_{2}$ & 1.000000 & & & & & \\
\hline GDP & 0.303563 & \begin{tabular}{|l|}
1.000000 \\
\end{tabular} & & & & \\
\hline TR & -0.292804 & 0.693358 & 1.000000 & & & \\
\hline PCC & 0.705349 & 0.055085 & -0.222874 & 1.000000 & & \\
\hline POC & 0.589361 & 0.239650 & -0.230546 & 0.584300 & 1.000000 & \\
\hline PGC & 0.322109 & 0.433350 & 0.354559 & 0.407371 & 0.583979 & 1.000000 \\
\hline \multicolumn{7}{|c|}{ D-8(Model 1.1) } \\
\hline & $\mathrm{CO} 2$ & GDP & TR & ENG & & \\
\hline $\mathrm{CO}_{2}$ & 1.000000 & & & & & \\
\hline GDP & 0.710737 & 1.000000 & & & & \\
\hline TR & 0.628541 & \begin{tabular}{|l|}
0.879787 \\
\end{tabular} & 1.000000 & & & \\
\hline ENG & 0.754987 & 0.909515 & 0.836946 & 1.000000 & & \\
\hline \multicolumn{7}{|c|}{ G-7(Model 2.1) } \\
\hline $\mathrm{CO}_{2}$ & 1.000000 & & & & & \\
\hline GDP & 0.302555 & 1.000000 & & & & \\
\hline TR & -0.293099 & 0.694813 & 1.000000 & & & \\
\hline ENG & 0.506441 & 0.355734 & 0.060423 & 1.000000 & & \\
\hline
\end{tabular}

\section{Results And Discussion}

LLC and IPS unit root tests are used initially to examine the stationarity of data. Some variables are stationary at the level and some at the level. Results are presented in appendix table 1(a). cross-sectional dependence (CD) of the variables and model was also checked, and results are presented in Table 3. All test statistics are significant, confirms the presence of $C D$ and analysis can proceed second generation unit root test.

Table 3 Cross-sectional dependence Test D-8 and G-7 Countries 


\begin{tabular}{|c|c|c|c|c|}
\hline Variables & BP LM & PS LM & BCS LM & Pesaran CD \\
\hline \multicolumn{5}{|c|}{ D-8 } \\
\hline & Statistics & Statistics & Statistics & Statistics \\
\hline $\mathrm{LCO}_{2}$ & $811.615^{* * *}$ & $121.994^{* * *}$ & $121.904^{* * *}$ & $28.488^{* * *}$ \\
\hline LGDP & $716.445^{* * *}$ & $107.309^{* * *}$ & $107.219^{* * *}$ & $26.646^{* * *}$ \\
\hline LTR & $670.777^{* * *}$ & $100.262^{* * *}$ & $100.173^{* * *}$ & $25.795^{* * *}$ \\
\hline LPCC & $322.478^{* * *}$ & $46.519^{* * *}$ & $46.419^{* * *}$ & $6.232^{* * *}$ \\
\hline LPOC & $375.064^{* * *}$ & $54.633^{* * *}$ & $54.543^{* * *}$ & $15.161^{* * *}$ \\
\hline LPGC & $730.792^{* * *}$ & $109.492^{* * *}$ & $109.402^{* * *}$ & $26.999^{* * *}$ \\
\hline \multicolumn{5}{|c|}{ G-7 } \\
\hline LCO2 & $317.764^{* * *}$ & $45.791^{* * *}$ & $45.702^{* * *}$ & $12.351^{* * *}$ \\
\hline LGDP & $745.981^{\text {*** }}$ & $111.867^{* * *}$ & $111.777^{* * *}$ & $27.271^{* * *}$ \\
\hline LTR & $823.558^{* * *}$ & $123.837^{* *}$ & $123.747^{* * *}$ & $28.697^{* * *}$ \\
\hline LPCC & $410.451^{* * *}$ & $60.093^{* * *}$ & $60.003^{* * *}$ & $8.536^{* * *}$ \\
\hline LPOC & $446.896^{* * *}$ & $65.717^{* * *}$ & $65.627^{* * *}$ & $18.452^{* * *}$ \\
\hline LPGC & $467.854^{* * *}$ & $68.951^{* * *}$ & $68.861^{* * *}$ & $19.919^{* * *}$ \\
\hline \multicolumn{5}{|c|}{ CD Test for Models } \\
\hline & \multicolumn{2}{|c|}{$\mathrm{D}-8$} & \multicolumn{2}{|c|}{ G-7 } \\
\hline & Model 1 & Model 2 & Model 1 & Model 2 \\
\hline BP LM & $175.837^{* * *}$ & $867.299^{* * *}$ & $176.351^{* * *}$ & $165.5672^{* * *}$ \\
\hline PS LM & $23.892^{* * *}$ & $112.156^{* * *}$ & $23.971^{* * *}$ & $22.30721^{* * *}$ \\
\hline Pesaran CD & $7.527^{* * *}$ & $28.779^{* * *}$ & $9.389^{* * *}$ & $9.254269^{* * *}$ \\
\hline
\end{tabular}

Second-generation unit root tests have been used as CD is confirmed because it allows CD and heterogeneity across the panel. CIPs and CADF tests were used to examine the stationarity of data at both level and first difference. Mostly, Variables are stationary at first difference. Most of the variables are stationary at first difference.

Table 4 Panel Unit Root Test 


\begin{tabular}{|c|c|c|c|c|}
\hline \multicolumn{5}{|c|}{$\mathrm{D}-8$} \\
\hline Variables & \multicolumn{2}{|c|}{ CADF } & \multicolumn{2}{|c|}{ CIPS } \\
\hline & Level & 1st Difference & Level & \begin{tabular}{|l|} 
1st Difference \\
\end{tabular} \\
\hline $\mathrm{LCO}_{2}$ & $-2.399^{* * *}$ & $-7.038^{* * *}$ & $-2.773^{* * *}$ & $-6.010^{* * *}$ \\
\hline LGDP & -0.598 & $-3.538^{* * *}$ & -1.789 & $-4.154^{* * *}$ \\
\hline LTR & -0.743 & $-6.119^{* * *}$ & -1.948 & $-5.328^{* * *}$ \\
\hline LPCC & $-2.569^{* * *}$ & $-5.541^{* * *}$ & $-2.618^{* * *}$ & $-5.928^{* * *}$ \\
\hline LPOC & $-1.323^{*}$ & $-6.017^{* * *}$ & -1.988 & $-5.557^{* * *}$ \\
\hline LPGC & -0.933 & $-5.857^{* * *}$ & -2.066 & $-5.036^{* * *}$ \\
\hline LENG & -1.174 & $-8.530^{* * *}$ & $-2.470^{* *}$ & $-5.938^{* * *}$ \\
\hline \multicolumn{5}{|c|}{ G-7 } \\
\hline $\mathrm{LCO}_{2}$ & -0.218 & $-10.239^{* * *}$ & -1.913 & $-6.021^{* * *}$ \\
\hline LGDP & -0.343 & $-5.424^{* * *}$ & -1.712 & $-3.941^{* * *}$ \\
\hline LTR & $-2.256^{* * *}$ & $-9.119^{* * *}$ & $-2.695^{* * *}$ & $-6.037^{* * *}$ \\
\hline LPCC & 0.436 & $-8.925^{* * *}$ & -1.672 & $-4.851^{* * *}$ \\
\hline LPOC & $-2.730^{* * *}$ & $-6.859^{* * *}$ & $-3.327^{* * *}$ & $-5.122^{* * *}$ \\
\hline LPGC & -0.696 & $-7.726^{* * *}$ & $-2.250^{* *}$ & $-5.262^{* * *}$ \\
\hline LENG & -0.819 & $-8.887^{* * *}$ & -2.195 & $-6.064^{* * *}$ \\
\hline
\end{tabular}

Here this study uses two prominent panel cointegration tests and the results of Pedroni, Kao cointegration tests are presented in appendix table 1(b). All the tests confirm the presence of cointegration. The Results of the Westerlund cointegration are presented in table 5 . In both regions study variables are cointegrated. Panel and group test confirm the existence of cointegration. The null hypothesis is rejected.

Table 5 Westerlund cointegration Test D-8 Countries 


\begin{tabular}{|c|c|c|c|c|}
\hline \multicolumn{5}{|c|}{ D-8 Model 1} \\
\hline Statistics & Value & Z-value & P-value & Robust P-value \\
\hline Gt & -3.641 & -2.18 & 0.013 & $0.000^{* * *}$ \\
\hline $\mathrm{G}_{\mathrm{a}}$ & -15.992 & 0.320 & 0.625 & $0.000^{* * *}$ \\
\hline$\overline{\mathrm{P}_{\mathrm{t}}}$ & -8.904 & -1.939 & 0.026 & $0.000^{* * *}$ \\
\hline$\overline{P_{a}}$ & -15.721 & -0.706 & 0.240 & $0.000^{* * *}$ \\
\hline \multicolumn{5}{|c|}{ D-8 Model 2} \\
\hline Gt & -2.540 & -0.262 & 0.397 & $0.000^{* * *}$ \\
\hline $\mathrm{G}_{\mathrm{a}}$ & -11.474 & -0.512 & 0.696 & $0.000^{* * *}$ \\
\hline $\mathrm{P}_{\mathrm{t}}$ & -5.492 & 0.177 & 0.570 & $0.000^{* * *}$ \\
\hline$\overline{P_{a}}$ & -9.110 & 0.068 & 0.527 & $0.000^{* * *}$ \\
\hline \multicolumn{5}{|c|}{ G-7 Model 1} \\
\hline Gt & $\begin{array}{l}-3.874 \\
\end{array}$ & -2.857 & 0.002 & 0.050 \\
\hline $\mathrm{G}_{\mathrm{a}}$ & -15.555 & 0.450 & 0.673 & 0.000 \\
\hline$\overline{P_{t}}$ & -10.470 & -3.394 & 0.000 & 0.000 \\
\hline$\overline{P_{a}}$ & -16.298 & -0.876 & 0.191 & 0.000 \\
\hline \multicolumn{5}{|c|}{ G-7 Model 2} \\
\hline Gt & -2.991 & -1.512 & 0.065 & 0.050 \\
\hline $\mathrm{G}_{\mathrm{a}}$ & -12.530 & 0.147 & 0.559 & 0.050 \\
\hline$\overline{P_{t}}$ & -8.477 & -2.579 & 0.005 & 0.050 \\
\hline$\overline{P_{a}}$ & -13.290 & -1.390 & 0.082 & 0.000 \\
\hline
\end{tabular}

Table 7 column 1-2, \& 3-4 explains the findings of Fully modified OLS and dynamic OLS in D-8 and G-7 countries, respectively., the coefficient of GDP per capita is positive and significant in the case of D-8 economies as $1 \%$ increase in GDP causes $\mathrm{CO}_{2}$ emissions to escalate by $3.721 \%, 5.320 \%$ as results shown by FMOLS and DOLS respectively. Moreover, the coefficient of square of GDP per capita, as shown by both estimators are negative and significant. As $1 \%$ increase in square of GDP per capita causes $\mathrm{CO}_{2}$ emissions to decrease by $-0.515 \%$, and $-0.703 \%$. Result confirms the existence of the EKC hypothesis in the case of D-8 countries as the initial phases of development are associated with ecological degradation but after a certain threshold level ecological degradation tends to decrease (Hanif et al., 2019; Ozturk \& Acaravi, 2013; Grossman \& Krueger, 1991). On the other side, GDP per capita coefficient is negatively and statistically significant associated with $\mathrm{CO}_{2}$ emissions in the case of G-7 countries as 1 percent increase in GDP Causes improvements in ecological quality by $-2.913,-9.730 \%$ respectively (results of FMOLS, DOLS). Here GDP per capita has a negative and significant link with $\mathrm{CO}_{2}$ emissions and square of GDP per capita is positive and significant which supports U-shaped curve similar to the findings of (Destek \& Sarkodie, 2019).

Secondly, the findings of disaggregate energy consumption suggest that in the case of D-8 economies, the coefficients of coal, oil, gas consumption are positive and significant implying that 1 percent surge in oil, coal, gas consumption leads to elevate emissions by $0.04,0.32,0.31$ percent respectively. Though the magnitude of oil consumption is higher out of the aforementioned non-renewable resources. The findings of DOLS are same but differs in magnitude. According to a report published by the European Union Joint 
Research Centre, elaborated that the combustion of fossil fuel accounted for about 90 percent of total worldwide $\mathrm{CO}_{2}$ emissions (Oliver et al., 2012). However, the outcomes of the present study are similar to the outcomes of (Valadkhani et al.,2019). In the case of G-7 countries, the findings are similar as a rise by 1 percent raises in coal, oil, and gas consumption escalates emissions by $0.14,0.05,0.52$ percent respectively and findings of DOLS estimator is same. The findings are consistent with the outcomes of (Ahmad et al. 2016). In G-7 economies gas and oil consumption is more detrimental for the environment but lower magnitude than D-8 confirms that G-7 economies are also using green technologies to curb the level of emissions.

Thirdly, estimates obtained from shows that in column $1 \& 2$, the coefficient of trade is positive and significant suggesting that $1 \%$ increase in trade causes a surge in the level of emissions by $0.04 \%, 0.06 \%$. This result is in the line with the results of (Ozturk \& Acaravi, 2013; Al-Mulali \& Ozturk, 2015; Van Tran, 2020). In developing economies trade can affect ecological quality through various channels like if trade increases, energy demand will also increase, furthermore it will escalate the energy consumption repercussion will be a resurgence in emissions. Contrary to this, the findings of trade in the case of G-7 are as trade shows negative and significant association with $\mathrm{CO}_{2}$ emissions. Both estimators confirm that one percent surge in trade slackens the emissions by -0.01 percent. In the case developed economies, trade cannot be a source of boosting emissions because they usually use advance and eco-friendly technologies. Strick rules and regulations are also a hurdle in these economies in polluting environment. our findings are supported by (Ahmed et al. 2016; Jalil \& Mehmood, 2011; Managi et al. 2009; Aller et al. 2015).

\section{Table 7 FMOLS and DOLS Results}

\begin{tabular}{|c|c|c|c|c|}
\hline \multirow[b]{3}{*}{ Variable } & \multicolumn{2}{|c|}{$\mathrm{D}-8$} & \multicolumn{2}{|l|}{ G-7 } \\
\hline & 1 & 2 & 3 & 4 \\
\hline & $1 \mathrm{CO} 2$ & $1 \mathrm{CO} 2$ & $1 \mathrm{CO} 2$ & $1 \mathrm{CO} 2$ \\
\hline LGDP & $\begin{array}{c}3.721^{* * *} \\
(2.556)\end{array}$ & $\begin{array}{l}5.320^{* * *} \\
(14.173)\end{array}$ & $\begin{array}{c}-2.913^{* * *} \\
(-2.498)\end{array}$ & $\begin{array}{c}-9.730^{* *} \\
(2.054)\end{array}$ \\
\hline LGDP $^{2}$ & $\begin{array}{c}-0.515^{* * *} \\
(-2.529)\end{array}$ & $\begin{array}{c}-0.703^{* * *} \\
(-9.642)\end{array}$ & $\begin{array}{c}0.332^{* * * *} \\
(2.582)\end{array}$ & $\begin{array}{l}1.084^{* *} \\
(2.099)\end{array}$ \\
\hline LTR & $\begin{array}{c}0.049^{* * *} \\
(4.458)\end{array}$ & $\begin{array}{c}0.062^{* * *} \\
(3.898) \\
\end{array}$ & $\begin{array}{c}-0.014^{* * *} \\
(-2.767) \\
\end{array}$ & $\begin{array}{c}-0.018^{* *} \\
(-2.136) \\
\end{array}$ \\
\hline LPCC & $\begin{array}{l}0.041^{* *} \\
(2.322)\end{array}$ & $\begin{array}{c}0.086^{* * *} \\
(2.829)\end{array}$ & $\begin{array}{l}0.147^{* * * *} \\
(17.718)\end{array}$ & $\begin{array}{c}0.231^{* * * *} \\
(5.942)\end{array}$ \\
\hline LPOC & $\begin{array}{c}0.321^{\text {***** }} \\
(6.022)\end{array}$ & $\begin{array}{c}0.269^{* * * *} \\
(3.523)\end{array}$ & $\begin{array}{c}0.054^{* * *} \\
(3.775)\end{array}$ & $\begin{array}{c}0.228^{\text {**** }} \\
(4.033)\end{array}$ \\
\hline LPGC & $\begin{array}{c}0.314^{* * *} \\
(9.753)\end{array}$ & $\begin{array}{c}0.286^{* * *} \\
(7.627)\end{array}$ & $0.520^{* * *}(17.326)$ & $\begin{array}{c}0.130^{*} \\
(1.588)\end{array}$ \\
\hline
\end{tabular}

\section{FMOLS and DOLS Results with Aggregate Energy Consumption}

In Table 8 column 1-2, 3-4 explain the estimates of the same model with aggregate energy consumption. Results obtained from FMOLS and DOLS, in this case, show that in D-8 countries coefficient of GDP per capita is also positive and significant highlighting that, $1 \%$ increase in GDP per capita causes $\mathrm{CO}_{2}$ 
emissions to escalate by 3.19, 2.03\%. However, the result reveals are the same as the findings of (Zoundi, 2017). The square of GDP per capita confirm the presence of the EKC hypothesis in D-8 countries. The result supports the existence of the EKC hypothesis in the case of D-8 countries (Hanif et al., 2019). However, aggregate energy consumption is a second significant contributor that enhances $\mathrm{CO}_{2}$ emissions by $1.25,0.91 \%$ if there is 1 percent surge in the usage of energy consumption as examined by (Alam et al., 2016). Trade is positively associated with $\mathrm{CO}_{2}$ emissions concludes that one percent increase in trade elevates $\mathrm{CO}_{2}$ emissions by $0.05 \%, 0.11 \%$.

In G-7 economies, according to the estimates of FMOLS, the sign of parameter of GDP per capita is negative highlighting that $1 \%$ surge in GDP per capita leads to a decline in emissions by $-2.99 \%$ and $-1.08 \%$. Furthermore, Square GDP per capita coefficient is positive and significant supporting the U-shaped EKC hypothesis. The finding of the current study, in this case, are supported by (Destek \& Sarkodie, 2019). Moreover, aggregate energy consumption in G-7 has positive and significant coefficient associated with $\mathrm{CO}_{2}$ emissions. As $1 \%$ increment in energy usage leads to boost $\mathrm{CO}_{2}$ emissions by $0.60 \%, 0.27 \%$. According to existing literature more energy usage is a significant factor in boosting environmental pollution. Thus, the result of the present study are consistent with the findings of (kasman \& Duman, 2015; Acheampong, 2018). The coefficient of trade is negative and significant implying that 1 percent increase in decline $\mathrm{CO}_{2}$ emissions by -0.54 and -0.38 percent. Trade findings in the case G-7 countries show that trade is not a significant factor in escalating $\mathrm{CO}_{2}$ emissions (Jalil \& Mehmood, 2009).

From the above discussion, it can be concluded that, the major contributor in escalating carbon emissions include economic growth, disaggregate and aggregate energy use. Trade is also a factor boosting the level of carbon emissions in D-8 economies, but trade is not a major contributor. EKC is valid in D-8 countries. In the case of G-7 economies, trade, growth is not a significant factor elevating carbon emissions. But both aggregate and disaggregate energy usage in economies are the major contributor in boosting carbon emissions

Table 8 FMOLS and DOLS Results with Aggregate Energy Consumption

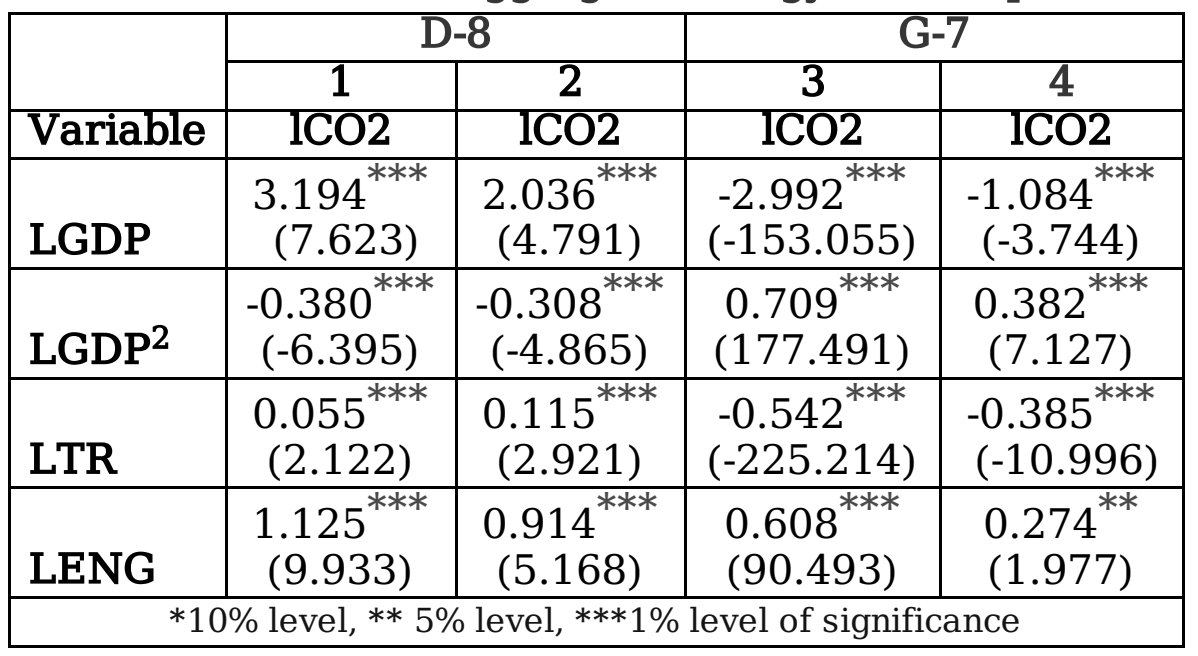

To check further robustness of the results study used heterogeneous static and dynamic estimators. The results of MG, AMG, CCEMG, and DCCEMG are presented in table 9, which will elaborate the findings in the 
case of both D-8 and G-7 countries. Tables 9, column 1-4 explaining the findings of MG, AMG, CCEMG, and DCCEMG. In the case of D-8 countries, column 1 elaborates the findings of MG. The results of columns 1 and 4 show that GDP per capita is a positive factor in deteriorating ecological quality. It also confirms the existence of the EKC hypothesis as discussed in the findings of previous estimators.

Coal consumption has positive but statistically significant as shown in columns 3 and four of table 11. Similarly, the findings of columns 1,2, and 3 highlights that oil consumption is also a significant factor in boosting carbon emissions. Lastly, the results explain that gas consumption is also contributing to emissions. Trade coefficient is positive and significant, and findings are similar in columns 2, 3 and 4 as well. On contrary, column 5-8 present findings in the case of G-7 economies as However, the findings of GDP, the square of GDP, and the results of disaggregated energy consumptions are robust and similar as discussed in previous results (FMOLS, DOLS). Trade is a negative but statistically insignificant factor in escalating $\mathrm{CO}_{2}$ emissions and the same results drawn in the study of (Jalil \& Mehmood, 2011).

Table 9: Static and Dynamic Heterogeneous Estimators Results

\begin{tabular}{|c|c|c|c|c|c|c|c|c|}
\hline & & & $\bar{D}-8$ & & & & G-7 & \\
\hline & 1 & 2 & 3 & 4 & 5 & 6 & 7 & 8 \\
\hline Variables & MG & AMG & CCEMG & DCCEMG & MG & AMG & CCEMG & DCCEMG \\
\hline LGDP & $5.45^{*}$ & $3.23^{* * *}$ & $5.004^{*}$ & $5.28^{* *}$ & $-11.40^{*}$ & -0.11 & 7.57 & 7.25 \\
\hline & $(2.83)$ & $(0.79)$ & $(2.733)$ & $(2.32)$ & $(6.47)$ & $(4.79)$ & $(8.38)$ & $(8.13)$ \\
\hline$\overline{\mathrm{LGDP}^{2}}$ & $-0.74^{*}$ & $-0.43^{* * *}$ & $-0.705^{*}$ & $-0.75^{* *}$ & $1.28^{*}$ & 0.03 & -0.86 & -0.81 \\
\hline & $(0.42)$ & $(0.13)$ & $(0.375)$ & $(0.32)$ & $(0.71)$ & $(0.53)$ & $(0.93)$ & $(0.90)$ \\
\hline LTR & $0.04^{* *}$ & $0.02^{* * *}$ & $0.0461^{*}$ & $0.05^{*}$ & -0.01 & 0.01 & -0.01 & -0.00 \\
\hline & $(0.02)$ & $(0.01)$ & $(0.0286)$ & $(0.03)$ & $(0.01)$ & $(0.01)$ & $(0.03)$ & $(0.04)$ \\
\hline LPOC & $0.30^{\text {*** }}$ & $0.14^{* *}$ & $0.136^{* * *}$ & 0.10 & $0.39^{* * *}$ & $0.27^{* * *}$ & $0.34^{* * *}$ & $0.35^{* * *}$ \\
\hline & $(0.06)$ & $(0.07)$ & $(0.0442)$ & $(0.06)$ & $(0.03)$ & $(0.04)$ & $(0.09)$ & $(0.10)$ \\
\hline$\overline{\mathrm{PPCC}}$ & 0.05 & 0.07 & $0.0942^{* *}$ & $0.09^{*}$ & $0.14^{* * *}$ & $0.16^{* * *}$ & $0.18^{* * * *}$ & $0.16^{* * *}$ \\
\hline & $(0.05)$ & $(0.05)$ & $(0.0458)$ & $(0.05)$ & $(0.03)$ & \begin{tabular}{|l}
$(0.02)$ \\
\end{tabular} & $(0.04)$ & $(0.04)$ \\
\hline LPGC & $0.28^{* * *}$ & $0.08^{*}$ & $0.113^{*}$ & $0.10^{*}$ & $0.20^{* * *}$ & $0.18^{* * *}$ & $0.16^{* * *}$ & $0.14^{* * *}$ \\
\hline & $(0.08)$ & $(0.05)$ & $(0.0691)$ & $(0.05)$ & $(0.03)$ & $(0.02)$ & $(0.03)$ & \begin{tabular}{|l|}
$(0.03)$ \\
\end{tabular} \\
\hline L.LCO 2 & - & - & - & -0.00 & - & - & - & $0.09^{*}$ \\
\hline & & & & $(0.06)$ & & & & $(0.05)$ \\
\hline Jonstant & -0.58 & 0.70 & 5.54 & - & $35.39^{* *}$ & 9.57 & -5.87 & - \\
\hline & $(5.33)$ & $(1.57)$ & $(5.01)$ & & (14.72) & \begin{tabular}{|l}
$(11.00)$ \\
\end{tabular} & $(9.10)$ & \\
\hline RMSE & 0.02 & 0.02 & 0.02 & 0.02 & 0.01 & 0.01 & 0.01 & 0.01 \\
\hline בD Statistics & & & & -3.00 & & & & -3.80 \\
\hline Jbservations & 280 & 280 & 280 & 273 & 280 & 280 & 280 & 273 \\
\hline$\overline{R^{2}}$ & - & 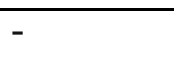 & - & 0.518 & & & & 0.388 \\
\hline Adjusted $R^{2}$ & 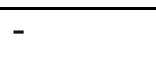 & - & - & 0.006 & & & & 0.044 \\
\hline
\end{tabular}

Somehow to further clarify the results, table 10 presents country-specific analysis, as in the case of D-8 economies the relationship of trade with emissions in Malaysia, Pakistan, Turkey, and Indonesia is positive, negative in Egypt but insignificant in the case of Iran and Bangladesh. The association of GDP with $\mathrm{CO}_{2}$ emissions is positive and significant in Bangladesh, Egypt, Malaysia, Pakistan, Turkey, and in Iran, 
Indonesia it is negative and insignificant. EKC hypothesis is confirmed in Bangladesh, Egypt, Malaysia, Pakistan, Turkey but not supported in Indonesia and Iran. Oil, coal, and gas consumption have a positive and statistically significant on emissions in all D-8 countries.

The results of country-specific analysis in G-7 countries indicate that trade has a negative relation in the UK, USA, and positive in Canada and Italy. GDP has a negative and statistically significant indicator and confirms the presence of a U-shaped curve in all G-7 countries except Canada. All the indicators of disaggregate energy consumption are damaging environment in G-7 countries. Our findings to some extend are consistent with the outcomes of (Ike et al., 2020).

Table 10 FMOLS Country Specific Analysis D-8 and G-7 Countries

\begin{tabular}{|c|c|c|c|c|c|c|}
\hline \multicolumn{7}{|c|}{ D-8 } \\
\hline Country & LGDP & LGDP $^{2}$ & LTR & LPCC & LPOC & LPGC \\
\hline BGD & $\begin{array}{l}12.85^{* * *} \\
(22.12)\end{array}$ & $\begin{array}{l}-2.12^{* * *} \\
(-22.53)\end{array}$ & $\begin{array}{c}0.01 \\
(1.26)\end{array}$ & $\begin{array}{l}0.03^{* * * *} \\
(9.33)\end{array}$ & $\begin{array}{l}0.12^{* * *} \\
(7.78)\end{array}$ & $\begin{array}{c}0.47^{* * *} \\
(33.11)\end{array}$ \\
\hline EGY & $\begin{array}{c}0.81 \\
(0.65)\end{array}$ & $\begin{array}{l}0.10^{* * *} \\
(0.53)\end{array}$ & $\begin{array}{c}-0.03^{* * *} \\
(-4.42)\end{array}$ & $\begin{array}{c}-0.02^{* * *} \\
(-2.58)\end{array}$ & $\begin{array}{l}0.77^{* * *} \\
(5.59)\end{array}$ & $\begin{array}{l}0.16^{* * *} \\
(6.21)\end{array}$ \\
\hline IRN & $\begin{array}{c}-9.83^{* * *} \\
(5.94)\end{array}$ & $\begin{array}{l}1.32^{* * *} \\
(5.91)\end{array}$ & $\begin{array}{l}-0.00 \\
(-0.33)\end{array}$ & $\begin{array}{l}0.15^{* * *} \\
(6.47)\end{array}$ & $\begin{array}{l}1.10^{* * *} \\
(2.96)\end{array}$ & $\begin{array}{l}0.53^{* * *} \\
(75.88)\end{array}$ \\
\hline IND & $\begin{array}{l}1.41 \\
(0.25)\end{array}$ & $\begin{array}{c}-0.15 \\
(-0.19)\end{array}$ & $\begin{array}{l}0.11^{* * *} \\
(2.85)\end{array}$ & $\begin{array}{c}0.04 \\
(1.06)\end{array}$ & $\begin{array}{c}0.39^{*} \\
(1.67)\end{array}$ & $\begin{array}{c}0.19 \\
(0.89)\end{array}$ \\
\hline MYS & $\begin{array}{l}3.29^{* *} \\
(1.98)\end{array}$ & $\begin{array}{l}-0.35^{*} \\
(-1.70)\end{array}$ & $\begin{array}{l}0.11^{* * *} \\
(4.67)\end{array}$ & $\begin{array}{l}0.06^{* * * *} \\
(4.10)\end{array}$ & $\begin{array}{l}1.70^{* * * *} \\
(14.58)\end{array}$ & $\begin{array}{c}0.16^{\text {*** }} \\
(5.44)\end{array}$ \\
\hline PAK & $\begin{array}{l}12.72^{* * *} \\
(18.22)\end{array}$ & $\begin{array}{l}-1.89^{* * *} \\
(-16.43)\end{array}$ & $\begin{array}{l}0.03^{* * *} \\
(5.06)\end{array}$ & $\begin{array}{l}-0.90^{* * *} \\
(-15.12)\end{array}$ & $\begin{array}{l}2.80^{* * *} \\
(20.27)\end{array}$ & $\begin{array}{l}2.46^{* * *} \\
(29.40)\end{array}$ \\
\hline TUR & $\begin{array}{l}7.27^{* * *} \\
(11.41)\end{array}$ & $\begin{array}{c}-0.84^{*} \\
(-11.10)\end{array}$ & $\begin{array}{l}0.06^{* * *} \\
(12.89)\end{array}$ & $\begin{array}{l}0.26^{* * *} \\
(19.21)\end{array}$ & $\begin{array}{l}0.12^{* * * *} \\
(5.88)\end{array}$ & $\begin{array}{l}0.02^{* * *} \\
(11.07)\end{array}$ \\
\hline \multicolumn{7}{|c|}{ G-7 } \\
\hline CAN & $\begin{array}{l}-9.57 \\
(-5.95)\end{array}$ & $\begin{array}{l}1.07^{* * *} \\
(6.11)\end{array}$ & $\begin{array}{l}0.04^{* * * *} \\
(9.75)\end{array}$ & $\begin{array}{l}0.16^{* * * *} \\
(18.39)\end{array}$ & $\begin{array}{l}0.38^{* * *} \\
(19.51)\end{array}$ & $\begin{array}{c}0.35 \\
(18.58)\end{array}$ \\
\hline FRA & $\begin{array}{c}-36.40^{* * * *} \\
(-10.63)\end{array}$ & $\begin{array}{l}4.02^{* * * *} \\
(10.79)\end{array}$ & $\begin{array}{c}-0.01 \\
(-1.42)\end{array}$ & $\begin{array}{l}0.17^{* * * *} \\
(6.98)\end{array}$ & $\begin{array}{l}0.34 \\
6.78\end{array}$ & $\begin{array}{l}0.19^{* * * *} \\
(4.98)\end{array}$ \\
\hline DEU & $\begin{array}{l}5.52 \\
2.81\end{array}$ & $\begin{array}{l}-0.59 \\
-2.75\end{array}$ & $\begin{array}{l}-0.03 \\
-3.93\end{array}$ & $\begin{array}{l}0.16 \\
7.18\end{array}$ & $\begin{array}{l}0.50 \\
8.43\end{array}$ & $\begin{array}{l}0.11 \\
3.48\end{array}$ \\
\hline ITA & $\begin{array}{c}-20.03^{* * * *} \\
(-3.66)\end{array}$ & $\begin{array}{l}2.23^{* * * *} \\
(3.67) \\
\end{array}$ & $\begin{array}{c}-0.00 \\
(-0.31) \\
\end{array}$ & $\begin{array}{c}0.01 \\
(0.18) \\
\end{array}$ & $\begin{array}{l}0.40 \\
8.62 \\
\end{array}$ & $\begin{array}{c}0.24 \\
(2.51) \\
\end{array}$ \\
\hline JPN & $\begin{array}{c}-13.30^{* * * *} \\
(-9.38)\end{array}$ & $\begin{array}{l}1.49^{* * * *} \\
(10.15)\end{array}$ & $\begin{array}{c}0.02 \\
(3.80)\end{array}$ & $\begin{array}{l}0.14^{* * *} \\
(6.30)\end{array}$ & $\begin{array}{c}0.54 \\
37.55\end{array}$ & $\begin{array}{l}0.07^{* * *} \\
(4.57)\end{array}$ \\
\hline UK & $\begin{array}{l}-3.80^{* * *} \\
(-1.55)\end{array}$ & $\begin{array}{c}0.44^{*} \\
(1.61)\end{array}$ & $\begin{array}{l}-0.04^{* * *} \\
(-2.63)\end{array}$ & $\begin{array}{l}0.12^{* * * *} \\
(10.36)\end{array}$ & $\begin{array}{l}0.45^{* * *} \\
(6.63)\end{array}$ & $\begin{array}{l}0.13^{* * *} \\
(5.01)\end{array}$ \\
\hline USA & $\begin{array}{c}-3.75^{* * *} \\
(-3.29)\end{array}$ & $\begin{array}{l}0.46^{* * *} \\
(3.61)\end{array}$ & $\begin{array}{c}0.01 \\
(1.03)\end{array}$ & $\begin{array}{c}0.29^{* * * *} \\
(14.54)\end{array}$ & $\begin{array}{l}0.33^{* * *} \\
(7.67)\end{array}$ & $\begin{array}{l}0.21^{* * *} \\
(7.62)\end{array}$ \\
\hline
\end{tabular}

BGD Bangladesh, EGY Egypt, IRN Iran, IND Indonesia, MYS Malaysia, PAK Pakistan, TUR Turkey, CAN Canada, FRA France, DEU Germany, ITA Italy, JPN Japan, UK United Kingdom, USA United States of America. $* 10 \%$ level, $* * 5 \%$ level, ${ }^{* * *} 1 \%$ level of significance 
The study used a second-generation panel causality test to investigate the causality among variables. The result of Dumitrescu and Hurlin, (2012) are presented in table 11. The results reveal that there is unidirectional causality from $\mathrm{CO}_{2}$ to $\mathrm{GDP}, \mathrm{CO}_{2}$ to trade, $\mathrm{CO}_{2}$ to $\mathrm{PGC}, \mathrm{CO}_{2}$ to $\mathrm{POC}, \mathrm{GDP}$ to PCC and bidirectional causality from $P C C$ to $\mathrm{CO}_{2}$, in D-8 countries while in the case of G-7 economies findings are as follows: there is an existence of unidirectional causality from GDP to $\mathrm{CO}_{2}$, TR to $\mathrm{CO} 2, \mathrm{PGC}$ to $\mathrm{CO}_{2}$ and $\mathrm{PCC}$ to $\mathrm{CO}_{2}$, bidirectional causality from $\mathrm{POC}$ to $\mathrm{CO}_{2}$.

Table 11 Dumitrescu Hurlin Causality Test Result

\begin{tabular}{|c|c|c|c|c|}
\hline & Stat. & Findings & W-Stat. & ngs \\
\hline LGDP does not homogeneously cause $\mathrm{LCO}_{2}$ & 2.149 & & 3.392 & \\
\hline $\mathrm{LCO}_{2}$ does not homogeneously cause LGDP & $3.968^{* *}$ & $\mathrm{CO} 2 \rightarrow \mathrm{G}$ & 2.582 & $\mathrm{CO} 2$ \\
\hline LTR does not homogeneously cause $\mathrm{LCO}_{2}$ & 2.285 & $\mathrm{TR} \neq \mathrm{CO} 2$ & $561^{* * *}$ & $\mathrm{TR} \rightarrow \mathrm{CO} 2$ \\
\hline $\mathrm{LCO}_{2}$ does not homo & $624^{* * *}$ & $\mathrm{CO} 2 \rightarrow \mathrm{LTR}$ & 2.122 & $\overline{\mathrm{CO}}$ \\
\hline PCC does not homogeneously cause $\mathrm{LCO}_{2}$ & $691^{* * *}$ & $\mathrm{PCC} \leftrightarrow \mathrm{CO} 2$ & 3.425 & $\mathrm{PCC} \neq \mathrm{CC}$ \\
\hline $\mathrm{LCO}_{2}$ does not homo & $3.600^{*}$ & & $4.704^{* * *}$ & $\overline{\mathrm{C}}$ \\
\hline LPGC does not homogeneously cause $\mathrm{LCO}_{2}$ & 2.684 & $\neq \mathrm{CO} 2$ & 2.542 & $\mathrm{PG}$ \\
\hline es not homc & $4.434^{* * * *}$ & $\overline{\mathrm{GC}}$ & 2.257 & $\mathrm{CO} 2 \neq \mathrm{PC}$ \\
\hline LPOC does not homo & 3.037 & $\mathrm{POC} \neq$ & $5.359^{* * *}$ & $\mathrm{POC} \leftrightarrow \mathrm{CC}$ \\
\hline $\mathrm{LCO}_{2}$ does not homogeneously ca & 08 & $\mathrm{CO} 2 \neq \mathrm{POC}$ & $4.569^{* * *}$ & \\
\hline LTR does not homog & 60 & $\mathrm{TR} \neq \mathrm{GDP}$ & 3.043 & 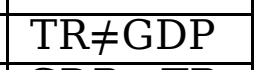 \\
\hline e LTR & 88 & & $4.098^{* * *}$ & $\rightarrow \mathrm{TR}$ \\
\hline LPCC does not hom & 1.931 & $\mathrm{PCC} \neq \mathrm{GDP}$ & 2.940 & $\overline{\mathrm{PCC}} \neq \mathrm{GD}$ \\
\hline LGDI & $417^{* *}$ & GD & & \\
\hline e LGDP & 40 & & 1.254 & $\mathrm{PG}$ \\
\hline LGDP does not hor & 1.285 & $\mathrm{GDP} \neq \mathrm{PGC}$ & 3.232 & $\mathrm{GDP} \neq \mathrm{P}$ \\
\hline LPOC does not homo & 2.177 & & & \\
\hline LGDP & 12 & & $4.213^{* * *}$ & \\
\hline LPCC does not ho & 2.806 & $\mathrm{PCC} \neq \mathrm{TR}$ & 2.494 & $\mathrm{PCC} \neq \mathrm{T}$ \\
\hline LTR does not homog & $4.424^{* * *}$ & $\mathrm{TR} \rightarrow \mathrm{PCC}$ & $4.200^{* * *}$ & $\mathrm{TH}$ \\
\hline & $7.936^{* * *}$ & $\rightarrow \mathrm{TR}$ & $3.810^{* *}$ & $\mathrm{PC}$ \\
\hline LPGC & 1.616 & $\mathrm{LTR} \neq \mathrm{PGC}$ & 2.708 & LTH \\
\hline es not hom & 2.271 & $\mathrm{POC} \neq \mathrm{LTR}$ & 2.742 & \\
\hline LPOC & $410^{* * * *}$ & & $0.374^{* * *}$ & $\bar{T}$ \\
\hline e LPCC & 3.15717 & $\mathrm{PGC} \neq \mathrm{PCC}$ & 1.830 & $\mathrm{PGC} \neq \mathrm{PC}$ \\
\hline LPCC does not hor & 2.06720 & $\mathrm{PCC} \neq \mathrm{PGC}$ & 2.796 & $\mathrm{PC}$ \\
\hline LPOC does not homo & 3.30178 & $\mathrm{POC} \neq \mathrm{PCC}$ & $4.438^{* * *}$ & $\overline{\mathrm{PO}}$ \\
\hline LPCC does not hon & 2.68295 & $\mathrm{PCC} \neq \mathrm{POC}$ & $3.841^{* *}$ & \\
\hline LPOC does not homogeneously c & 1.87901 & $\mathrm{POC} \neq 1$ & $4.585^{*}$ & \\
\hline LPGC does not homogeneously cause LPOC & $18516^{* *}$ & & & \\
\hline
\end{tabular}




\section{Conclusion}

Ecological degradation is a very pressing topic that has been under discussion since the $20^{\text {th }}$ century. This study examines the dynamics links among $\mathrm{CO}_{2}$ emissions, trade, GDP, aggregate, and disaggregate energy consumption for D-8 and G-7 countries utilizing the annual data between 1980 and 2019. The empirical analysis is based on both first and second-gen panel time series analysis. The study takes care of different econometric concerns such as endogeneity, heterogeneity, and cross-sectional dependence using static and dynamic panel estimators.

The results of both Pedroni, Kao, and Westerlund cointegration test confirm the long-run association among all the study variables. The findings of FMOLS, DOLS and heterogenous dynamic panel estimators conclude that the GDP per capita, aggregate and disaggregate energy consumption (i-e oil, coal, gas consumption), trade are the significant factors of $\mathrm{CO}_{2}$ emissions in the panel of D-8 countries. The results accept the EKC hypothesis for the panel D-8 economies implying that the existing development policy framework in these countries has the potential to recover the environmental loss caused by growth-oriented policies in the long run. However, a better and improved policy framework can shorten the transitionary spell between for- and pro-environment growth periods.

The results for G-7 countries reveal that GDP and trade have a negative effect on $\mathrm{CO}_{2}$ emissions. Besides, the existence of a U-shaped curve is validated in G-7 economies. G-7 countries are following strict environmental rules and regulations but at the same time due to economies of scale and large-scale production, they are also facing the challenge of high emissions. The findings validate that aggregate and disaggregate energy consumption, and GDP are highly emission intensive. Trade deleterious for the environment in D-8 countries.

Findings of the study suggest that D-8 economies need to adopt green strategies, green technologies and must ensure sustainable patterns for production and consumption. Renewable energy has the potential to meet the growing demands of energy with improving ecological quality. The integration of more effective, advanced and green, and clean technologies is mandatory for an effective transition from fossil fuel usage while attaining a decarbonized economy. Public, private sectors should substitute conventional sources with advance, clean and green resources.

\section{Declarations}

Authors' contributions This idea was given by Muhammad Tariq Majeed. Muhammad Tariq Majeed supported in all sections of this work and completed the final write up of the paper. Naveed Asghar analysed the data and discussed the results and drafted initial versions of the other sections. All authors have read and approved the manuscript.

Conflict of Interest: Authors declare that they have no conflict of interest.

Ethical Approval: This article does not contain any studies with human participants or 
animals performed by any of the authors.

Finding: No funding from any institute is received for this study.

Availability of Data: Data sources are clearly mentioned. Interested person can access the data.

Computational Codes: Computational codes are available on demand.

Consent to Participate: I am free to contact any of the people involved in the research to seek further clarification and information.

Consent for publication: Not applicable

\section{Declaration of interest statement}

Declaration of interests $\otimes$ The authors declare that they have no known competing financial interests or personal relationships that could have appeared to influence the work reported in this paper.

\section{References}

Acheampong, A. O. (2018). Economic growth, $\mathrm{CO} 2$ emissions and energy consumption: What causes what and where? Energy Economics, 74, 677-692.

Ahmad, A., Zhao, Y., Shahbaz, M., Bano, S., Zhang, Z., Wang, S., \& Liu, Y. (2016). Carbon emissions, energy consumption and economic growth: An aggregate and disaggregate analysis of the Indian economy. Energy Policy, 96, 131-143.

Ahmed, K., Ozturk, I., Ghumro, I. A., \& Mukesh, P. (2019). Effect of trade on ecological quality: A case of D-8 countries. Environmental Science and Pollution Research, 26(35), 35935-35944.

Ahmed, K., Shahbaz, M., \& Kyophilavong, P. (2016). Revisiting the emissions-energy-trade nexus: Evidence from the newly industrializing countries. Environmental Science and Pollution Research, 23(8), 7676-7691.

Alam, M. M., Murad, M. W., Noman, A. H. M., \& Ozturk, I. (2016). Relationships among carbon emissions, economic growth, energy consumption and population growth: Testing Environmental Kuznets Curve hypothesis for Brazil, China, India and Indonesia. Ecological Indicators, 70, 466-479.

Alkhathlan, K., \& Javid, M. (2013). Energy consumption, carbon emissions and economic growth in Saudi Arabia: An aggregate and disaggregate analysis. Energy Policy, 62, 1525-1532.

Aller, C., Ductor, L., \& Herrerias, M. J. (2015). The world trade network and the environment. Energy Economics, 52, 55-68.

Al-Mulali, U., \& Ozturk, I. (2015). The effect of energy consumption, urbanization, trade openness, industrial output, and the political stability on the environmental degradation in the MENA (Middle East and North African) region. Energy, 84, 382-389. 
Al-mulali, U., \& Sheau-Ting, L. (2014). Econometric analysis of trade, exports, imports, energy consumption and $\mathrm{CO} 2$ emission in six regions. Renewable and Sustainable Energy Reviews, 33, 484-498.

Antweiler, W., Copeland, B. R., \& Taylor, M. S. (2001). Is free trade good for the environment? American Economic Review, 91(4), 877-908.

Apergis, N., Payne, J. E., Menyah, K., \& Wolde-Rufael, Y. (2010). On the causal dynamics between emissions, nuclear energy, renewable energy, and economic growth. Ecological Economics, 69(11), 2255-2260.

Baek, J. (2015). Environmental Kuznets curve for $\mathrm{CO} 2$ emissions: The case of Arctic countries. Energy Economics, 50, 13-17.

Bosupeng, M. (2016). The effect of exports on carbon dioxide emissions: Policy implications. International Journal of Management and Economics, 51(1), 20-32.

British Petroleum. (2019). British petroleum statistical review of world energy. British Petoleum: London UK. Available at: https://www.bp.com/en/global/corporate/energy-economics/statistical-review-of-worldenergy.html.

British Petroleum. (2020). British petroleum statistical review of world energy. British Petoleum: London UK. Available at: https://www.bp.com/content/dam/bp/business-sites/en/global/corporate/pdfs/energyeconomics/statistical-review/bp-stats-review-2020-full-report.pdf

British, P. (2018). BP statistical review of world energy, June 2015. London, UK: British Petroleum. Available at: https://www.bp.com/content/dam/bp/business-sites/en/global/corporate/pdfs/energy= economics/statistical-review/bp-stats-review-2018-full-report.

Carbon footprint, 2018. Carbon footprint climate change: Retrieved from: https://www.carbonfootprint.com/warming.html (2018).

Chandran, V. G. R., \& Tang, C. F. (2013). The impacts of transport energy consumption, foreign direct investment and income on $\mathrm{CO} 2$ emissions in ASEAN-5 economies. Renewable and Sustainable Energy Reviews, 24, 445-453.

Chudik, A., \& Pesaran, M. H. (2015). Common correlated effects estimation of heterogeneous dynamic panel data models with weakly exogenous regressors. Journal of Econometrics, 188(2), 393-420.

Destek, M. A., \& Sarkodie, S. A. (2019). Investigation of environmental Kuznets curve for ecological footprint: The role of energy and financial development. Science of the Total Environment, 650, 2483-2489.

Dogan, E., Seker, F., \& Bulbul, S. (2017). Investigating the impacts of energy consumption, real GDP, tourism and trade on $\mathrm{CO} 2$ emissions by accounting for cross-sectional dependence: A panel study of OECD countries. Current Issues in Tourism, 20(16), 1701-1719. 
Dumitrescu, E. I., \& Hurlin, C. (2012). Testing for Granger non-causality in heterogeneous panels. Economic modelling, 29(4), 1450-1460.

Eberhardt, M., \& Bond, S. (2009). Cross-section dependence in nonstationary panel models: A novel estimator.

Eckstein, D., Künzel, V., Schäfer, L., \& Winges, M. (2019). Global climate risk index 2020. Germanwatch, Retrieved from: https://germanwatch.org/sites/germanwatch. o2rg/files/20-2-01e\% 20Global, 20.

Energy Information Administration (US), \& Government Publications Office (Eds.). (2016). International Energy Outlook 2016, with Projections to 2040. Government Printing Office.

Global Footprint Network (2016) Global footprint network. Obtenido de Global Footprint Network: Retrieved from http://www.footprintnetwork.org online.

Gorus, M. S., \& Aydin, M. (2019). The relationship between energy consumption, economic growth, and CO2 emission in MENA countries: Causality analysis in the frequency domain. Energy, 168, 815-822.

Grossman, G. M., \& Krueger, A. B. (1991). Environmental impacts of a North American free trade agreement (No. w3914). National Bureau of economic research.

Grossman, G. M., \& Krueger, A. B. (1995). Economic growth and the environment. The quarterly journal of economics, $110(2), 353-377$.

Halicioglu, F., \& Ketenci, N. (2016). The impact of international trade on environmental quality: The case of transition countries. Energy, 109, 1130-1138.

Hanif, I., Raza, S. M. F., Gago-de-Santos, P., \& Abbas, Q. (2019). Fossil fuels, foreign direct investment, and economic growth have triggered $\mathrm{CO} 2$ emissions in emerging Asian economies: Some empirical evidence. Energy, 171, 493-501.

Holtz-Eakin, D., \& Selden, T. M. (1995). Stoking the fires? CO2 emissions and economic growth. Journal of public economics, 57(1), 85-101.

Ike, G. N., Usman, O., Alola, A. A., \& Sarkodie, S. A. (2020). Environmental quality effects of income, energy prices and trade: The role of renewable energy consumption in G-7 countries. Science of The Total Environment, 721, 137813.

IPCC. (2018). Special report on global warming of 1.5 _C. Incheon, Republic of Korea: Intergovernmental Panel on Climate Change. Available at: https://www.jpcc.ch/site/assets/uploads/2018/11/pr_181008_P48_spm_en.pdf.

Jalil, A., \& Mahmud, S. F. (2009). Environment Kuznets curve for CO2 emissions: A cointegration analysis for China. Energy Policy, 37(12), 5167-5172. 
Jayanthakumaran, K., Verma, R., \& Liu, Y. (2012). CO2 emissions, energy consumption, trade and income: A comparative analysis of China and India. Energy Policy, 42, 450-460.

Kahia, M., Jebli, M. B., \& Belloumi, M. (2019). Analysis of the impact of renewable energy consumption and economic growth on carbon dioxide emissions in 12 MENA countries. Clean Technologies and Environmental Policy, 21(4), 871-885.

Kao, C. (1999). Spurious regression and residual-based tests for cointegration in panel data. Journal of econometrics, 90(1), 1-44.

Kasman, A., \& Duman, Y. S. (2015). CO2 emissions, economic growth, energy consumption, trade and urbanization in new EU member and candidate countries: A panel data analysis. Economic Modelling, 44, 97-103.

Kearsley, A., \& Riddel, M. (2010). A further inquiry into the pollution haven hypothesis and the environmental Kuznets curve. Ecological Economics, 69(4), 905-919.

Kellenberg, D. K. (2009). An empirical investigation of the pollution haven effect with strategic environment and trade policy. Journal of international economics, 78(2), 242-255.

Khan, M. K., Teng, J. Z., \& Khan, M. I. (2019). Effect of energy consumption and economic growth on carbon dioxide emissions in Pakistan with dynamic ARDL simulations approach. Environmental Science and Pollution Research, 26(23), 23480-23490.

Kohler, M. (2013). CO2 emissions, energy consumption, income and foreign trade: A South African perspective. Energy Policy, 63, 1042-1050.

Kraft, J., \& Kraft, A. (1978). On the relationship between energy and GNP. The Journal of Energy and Development, 3(2), 401-403.

Le, T. H., Chang, Y., \& Park, D. (2016). Trade openness and environmental quality: International evidence. Energy Policy, 92, 45-55.

Lean, H. H., \& Smyth, R. (2010). CO2 emissions, electricity consumption and output in ASEAN. Applied Energy, 87(6), 1858-1864.

Li, H., Li, F., \& Yu, X. (2018). China's contributions to global green energy and low-carbon development: Empirical evidence under the Belt and Road Framework. Energies, 11(6), 1527.

Majeed, M. T., \& Mazhar, M. (2019). Financial development and ecological footprint: A global panel data analysis. Pakistan Journal of Commerce and Social Sciences (PJCSS), 13(2), 487-514.

Managi, S., Hibiki, A., \& Tsurumi, T. (2009). Does trade openness improve environmental quality? Journal of Environmental Economics and Management, 58(3), 346-363. 
Munir, K., \& Riaz, N. (2019). Energy consumption and environmental quality in South Asia: Evidence from panel non-linear ARDL. Environmental Science and Pollution Research, 26(28), 29307-29315.

Munir, K., \& Riaz, N. (2020). Asymmetric impact of energy consumption on environmental degradation: Evidence from Australia, China, and USA. Environmental Science and Pollution Research, 27, 11749-11759.

Narayan, P. K., \& Narayan, S. (2010). Carbon dioxide emissions and economic growth: Panel data evidence from developing countries. Energy Policy, 38(1), 661-666.

Olivier, J. G., Janssens-Maenhout, G., Muntean, M., \& Peters, J. A. H. W. (2012). Trends in global CO2 emissions; 2012 Report. PBL Netherlands Environmental Assessment Agency. Institute for Environment and Sustainability of the European Commission's Joint Research Centre.

Ozokcu, S., \& Ozdemir, Ö. (2017). Economic growth, energy, and environmental kuznets curve. Renewable and Sustainable Energy Reviews, 72, 639-647.

Ozturk, I., \& Acaravci, A. (2013). The long-run and causal analysis of energy, growth, openness and financial development on carbon emissions in Turkey. Energy Economics, 36, 262-267.

Panayotou, T. (1993). Empirical tests and policy analysis of environmental degradation at different stages of economic development. International Labor Organization. Working Papers, (992927783402676).

Pedroni, P. (1999). Critical values for cointegration tests in heterogeneous panels with multiple regressors. Oxford Bulletin of Economics and statistics, 61(S1), 653-670.

Pesaran, M. H. (2006). Estimation and inference in large heterogeneous panels with a multifactor error structure. Econometrica, 74(4), 967-1012.

Pesaran, M. H. (2007). A simple panel unit root test in the presence of cross-section dependence. Journal of Applied Econometrics, 22(2), 265-312.

Pesaran, M. H. (2015). Testing weak cross-sectional dependence in large panels. Econometric Reviews, 34(6-10), 1089-1117.

Pesaran, M. H., \& Smith, R. (1995). Estimating long-run relationships from dynamic heterogeneous panels. Journal of Econometrics, 68(1), 79-113.

Rahman, M. M. (2017). Do population density, economic growth, energy use and exports adversely affect environmental quality in Asian populous countries? Renewable and Sustainable Energy Reviews, 77, 506514.

Salman, M., Long, X., Dauda, L., Mensah, C. N., \& Muhammad, S. (2019). Different impacts of export and import on carbon emissions across 7 ASEAN countries: A panel quantile regression approach. Science of the total environment, 686, 1019-1029. 
Shafik, N., \& Bandyopadhyay, S. (1992). Economic growth and environmental quality: Time-series and cross-country evidence 904, World Bank Publications.

Shahbaz, M., Hye, Q. M. A., Tiwari, A. K., \& Leitão, N. C. (2013). Economic growth, energy consumption, financial development, international trade and $\mathrm{CO} 2$ emissions in Indonesia. Renewable and Sustainable Energy Reviews, 25, 109-121.

Stern, D. I., Common, M. S., \& Barbier, E. B. (1994). Economic Growth and Environmental Degradation: A critique of the environmental Kuznets curve(No. 2049-2017-5030).

Suri, V., \& Chapman, D. (1998). Economic growth, trade and energy: Implications for the environmental Kuznets curve. Ecological Economics, 25(2), 195-208.

Valadkhani, A., Nguyen, J., \& Bowden, M. (2019). Pathways to reduce CO2 emissions as countries proceed through stages of economic development. Energy Policy, 129, 268-278.

Van Tran, N. (2020). The environmental effects of trade openness in developing countries: Conflict or cooperation? Environmental Science and Pollution Research (2020), 27, 19783-19797.

Westerlund, J. (2007). Testing for error correction in panel data. Oxford Bulletin of Economics and Statistics, 69(6), 709-748.

Westerlund, J. (2008). Panel cointegration tests of the Fisher effect. Journal of Applied Econometrics, 23(2), 193-233.

World Bank. (2019). World development indicators. Washington DC: World Bank.

Zafar, M. W., Saud, S., \& Hou, F. (2019). The impact of globalization and financial development on environmental quality: Evidence from selected countries in the Organization for Economic Co-operation and Development (OECD). Environmental Science and Pollution Research, 26(13), 13246-13262.

Zoundi, Z. (2017). CO2 emissions, renewable energy and the environmental kuznets curve, a panel cointegration approach. Renewable and Sustainable Energy Reviews, 72, 1067-1075.

\section{Supplementary Files}

This is a list of supplementary files associated with this preprint. Click to download.

- Appendix.docx 